\title{
ENHANCING EFL STUDENTS' WILLINGNESS TO COMMUNICATE: TEACHERS' BELIEFS ABOUT THEIR ROLES AND STRATEGIES
}

\author{
Funny Amalia Sari \\ University of Exeter, England, United Kingdom \\ fas206@exeter.ac.uk
}

\begin{abstract}
This study aims to investigate teachers' beliefs about the scope of their roles in terms of interaction strategies in order to develop and maintain their learners' willingness to communicate (WTC). Four experienced teachers of two English courses in Indonesia were asked to answer an open self-completion questionnaire that was designed based on the three interaction strategies proposed by Lee and $\mathrm{Ng}$ (2010). The study suggests any pedagogic interventions always depend on good teaching: one method alone does not promise success. This present study is expected to contribute to the comprehension of teachers' influence to learners' WTC particularly to language teacher development.
\end{abstract}

Keywords: willingness to communicate, WTC, teacher interaction strategies, teachers' roles, teachers'beliefs

\begin{abstract}
Abstrak
Penelitian ini bertujuan mengeksplorasi keyakinan guru tentang ruang lingkup peran mereka pada strategi interaksi untuk meningkatkan dan mempertahankan kemauan siswa mereka untuk berkomunikasi (WTC). Empat guru bahasa Inggris berpengalaman di sebuah bimbingan belajar di Indonesia diberi kuesioner open self-completion yang didesain berdasarkan tiga strategi interaksi yang dicetuskan oleh Lee dan $\mathrm{Ng}$ (2010). Hasil penelitian ini menunjukkan bahwa intervensi pedagogik selalu tergantung pada pengajaran yang baik: satu metode tidak menjanjikan keberhasilan. Penelitian ini diharapkan dapat memberikan pengaruh pemahaman guru pada kemauan siswa untuk berkomunikasi (WTC) khususnya untuk pengembangan guru bahasa.
\end{abstract}

Kata Kunci: kemauan untuk berkomunikasi, WTC, strategi interaksi guru, peran guru, keyakinan guru

\section{Introduction}

A gamut of research has indicated that learners' active involvement in communication and interaction in their target language is essential during the learning process as modern language pedagogy specifically aims to enable learners to naturally communicate in their target language. Thus speaking plays an increasingly important role in language learning. This is in line with
Skehan (1989, cited in Zarrinabadi, 2014) who argues that learners' talk in the target language is fundamental to achieve $\mathrm{L} 2 / \mathrm{FL}$ (Foreign Language) proficiency; therefore, the learning process should place more emphasis on how to utilize classroom tasks largely to encourage students to demonstrate their linguistic competence within conversations. A lack of opportunities provided for learners to speak may cause them to remain 
as 'mute' language users regardless of extensive linguistic input they have received.

Besides the absence of opportunities to interact in target language, another possible reason that may hinder language learners from being capable of communicating in their target language is that they do not have Willingness to Communicate (WTC). The topic of WTC has been widely discussed as having a pivotal role in L2/FL learning. It is WTC that generates enthusiasm to seek out or even create opportunities to talk in the target language. McCroskey (1987) claims that WTC is proven as a predictor of classroom participation since students with high ranking WTC participated more in classroom interaction (cited in Liu and Jackson, 2008) and they are likely to be ready to get involved in any interactions using their L2 outside classrooms (Kang, 2005).

Since WTC is considered crucial, a notable strand of discussion has attempted to consider the impacts of its presence or absence and suggested numerous ways to facilitate this factor in language learning process especially within classroom environment. In the EFL (English as Foreign Language/ESL (English as a Second Language) classroom context, teachers undeniably exert a significant and determining influence on learner's engagement and WTC (Wen \& Clément, 2003; Peng,2007; Cao,2011; MacIntyre et al., 2011 cited in Zarrinabadi, 2014). Experts suggest teachers' attitude, involvement, and teaching style significantly affect learners' involvement and WTC (Wen \& Clément, 2003; Peng, 2007; MacIntyre et al., 2011; Cao, 2011 cited in Zarrinabadi, 2014).

Given the importance of teachers' contributions in generating and maintaining students' WTC in L2/FL, it seems essential to value teachers' beliefs of their roles and interaction strategies as their beliefs and perceptions may define their actual practices while teaching target language and employing instructional methods (Staub \& Stern, 2002 cited in Sadeghi et al., 2014).

Numerous studies published to date have shed light on direct or indirect correlation between teachers and WTC; however, how teachers' beliefs shape their decisions to perform particular roles and apply certain interaction strategies related to students' WTC still needs to be identified. The present study investigates teachers' beliefs of their roles and interaction strategies applied in their classrooms within Indonesian EFL learning classroom context.

This qualitative study examines the following research questions:

1. What are teachers' beliefs about their roles and interaction strategies in maintaining students' WTC?

2. How do teachers apply interaction strategies to maintain students' WTC?

The paper consists of five parts. The first part is the introduction which contains two research questions that outline this research. The second part is Literature Review that discusses four foci of this study; namely, teachers' beliefs, willingness to communicate, teachers' roles and teachers' interaction strategies. The next section explains the methodology of this research including descriptions of context and participants, data collection and data analysis. The fourth part presents findings and discussion which is organized based on the three interaction strategies: teacher-fronted strategy, facilitator-oriented strategy and learner-oriented strategy. The last section describes the conclusion, suggestions and limitations of this study.

\section{Literature Review}

This section discusses the results of previous studies related to the four elements in this research; namely, teachers' beliefs, willingness to communicate (WTC), teachers' roles and interaction strategies respectively.

\subsection{Teachers' Beliefs}

Teachers' beliefs hold a pivotal role in teachers' behavior, judgments, and deci- 
sions related their teaching practice. Pajares (1992) views teachers' beliefs as the single most important construct in educational research. In addition to that, Williams and Burden (1997) argue that teachers' beliefs are more influential than their knowledge or any methodologies they are told to adapt in organizing and defining classroom tasks and problems. They influence pedagogical decision-making, the acceptance and uptake of new approaches, techniques and activities, choice of subjects and classroom activities and evaluation in the classroom $(\mathrm{Li}, 2013)$.

Beliefs emerge as a result of past experience, present situation, and future plans (Clandinin \& Connelly, 2000), which indicates that they may change due to several factors, for example, interaction with students (Skott, 2001 cited in Li, 2013).

Highlighting teachers' beliefs as a fundamental element in teaching practices, it is worth investigating how they inform teachers' decisions to apply particular interaction strategies and roles to facilitate learners' WTC.

\subsection{Willingness to Communicate}

Experts argue that a language learning course is considered successful when it is able to produce students who are willing to seek out opportunities to talk in the target language, hence when it fails to craft students' willingness to use the target language, the program is simply a failure (MacIntyre et al., 1998). The fact is, however, many language learning classes are also filled with those who do not show, or perhaps do not have willingness to interact in their L2/ FL. An American psychologist and philosopher William James (1890 cited in MacIntyre, 2007: p.569) clearly describes this common situation as follows:

\footnotetext{
A significant number of L2 learners around the world brace themselves to the resolve, they learn another language, and they choose to speak in the language. For such people, a state is reached in which
}

\section{L2 communication is approached willingly, others seem destined to remain in the condition of wish and not will.}

One of the most influential elements in successful learning is, it will be argued, learners' WTC. Willingness to Communicate addresses the readiness of learners to engage in communication using their L2/ FL at a particular time with a specific person or persons when given the opportunity (McCroskey \& Richmond, 1990 cited in Zarrinabadi, 2014; MacIntyre et al., 1998). The state of readiness is established as the result of a combination of several factors: lack of anxiety and communicative competence which develop learners' self confidence in using the target language; and intention to engage in communication (MacIntyre et al., 1998). It means that WTC is a dynamic factor, that is, its presence depends on the existence of the aforementioned factors; conversely, the absence of those factors may result in learners' un-WTC.

Previous research indicates that elements of the language learning process within the classroom context that may promote learners' WTC are closely related to teachers, for example, topic, type of task, interlocutor interaction (teacher or peers) and pattern of interaction: teacher-fronted situation, dyad, and small group (Cao \& Philp, 2006; cited in Zarrinabadi, 2014). From the students' point of view, Cao (2011) identifies that they are likely to be willing to interact more when they like their teachers. According to Zarrinabadi's (2014) study, students tend to be more active using their L2/FL in their classroom when their teachers show them support to talk, for example, giving students sufficient time to think before answering questions; or allowing students to choose topics of discussion that are interesting for them. It can be concluded that teacher-related factors seem to significantly promote students' WTC.

\subsection{Teachers' Roles}

'Role' is a technical term used in 
sociology to point out the shared expectations of how an individual should behave (Dörnyei and Murphy, 2003). Teachers' roles refer to a list of expected teachers' pedagogical behaviours. Pedagogically, based on Harmer's framework (Hedge, 2000), EFL/ESL teachers' roles in language learning process can be identified as follows: as controllers, assessors, correctors, organizers, prompters and resources. Richards (2006, 2011; cited in Rido et al., 2014) propose three other roles: facilitators, monitors and mediators, while Littlewood (1981 cited in Choudhury, 2011) mentions teacher as a facilitator that includes some sub-roles such as: a supervisor of students' learning activities, a classroom manager, a consultant, an adviser, and on several occasions as a communicator with learners. Among the list of proposed teachers' roles, teachers generally manage to perform the following functions: instructors, organizers, counselors and helpers (Hedge, 2000). The ultimate aim of all roles performed by teachers is, indeed, to facilitate progress of students' language skills (Harmer, 1998). As a key professional competence, teachers should be able to stimulate students' interests and involvement in the classroom activities, even when their students do not seem to be interested in participating.

\subsection{Teachers' Interaction Strategies}

Creating a communicative language classroom has been an obligation for most language teachers nowadays. To do so, they need to ensure that the techniques they use in the classroom promote dynamic interaction with their students and interactions among students in the target language. Lee and Ng's (2009) study underlines three types of interaction strategies namely teacher-fronted strategy, facilitator-oriented strategy and learner-oriented strategy.

Teacher-fronted strategy is a controlled interaction pattern in which the teacher talks most of the time and initiates the exchange between her/him and the students. This approach is also known as IRF sequences, or triadic dialogue. The triplet involves three general steps: teacher initiates the questions, students respond to it as a class and teacher gives feedback in the forms of correction, acceptance or rejection of students' answers (Sinclair \& Coulthard, 1975 cited in Waring, 2008). The F step might also be intended to close a cycle and move to a new cycle of IRF marked by teacher posing another question. Although there are studies which criticize its rigid structure (van Lier, 2000b cited in Waring, 2008; Miao \& Heining-Boynton, 2011), IRF is still widely used in language classroom interaction (Kyriacou and Issitt, 2008 cited in Ingram and Elliot, 2014).

The second type of strategy, facilitator-oriented strategy, is a 'more let go' version of IRF in which the third step, F-move, serves as a follow up for teachers to continue the exchange. When applying this strategy, teachers do not attempt to give obvious feedback, but focus more on building class discussion (Cullen, 2002), therefore they do not cut the dialog, but let it flow by inviting more students to join in the conversation. This strategy involves topic personalization, referential questions, reformulation, elaboration, comment, repetition, backchannels, content-focused feedback and longer wait time (Lee and $\mathrm{Ng}, 2009$ ). Wider scope of F-move has changed the rigid pattern of IRF to be a more strategic discourse that supports language learning; providing that teachers do not merely evaluate students' answer but also attempt to invite students to collaborate in the discourse.

Thelastinteraction strategy mentioned in this study islearner oriented strategy or can also be defined as learner-learner interaction. This type of approach offers opportunities for students to speak in the classroom without direct teacher intervention (Lee \& Ng, 2010). It usually applies when students work as groups or dyads to accomplish a task. According to Ryoo (2009) students' collaborative interactions in the sociocultural framework enable them to mediate their understanding and actively 
seek solutions together to reach second language development. During students' group work, the teacher only intervenes during the interaction if necessary, for example, to help their students when they face problems in doing their tasks.

Experts may suggest one out of three approaches proposed by Lee and $\mathrm{Ng}$ (2009) is better than the others in facilitating WTC; however, the three interaction strategies are commonly used in language classrooms (Lee \& Ng, 2009). Every interaction strategy is embedded by particular teachers' roles; for example, teachers may perform as controllers of discourses in teacher-fronted strategy application or facilitators during facilitator-oriented or learner-oriented strategy. The decisions to apply or not to apply certain strategies are informed by the beliefs that teachers hold.

\section{Methodology}

This section presents an overview of the context and participants, data collection instrument and data analysis process.

\subsection{Context and Participants}

WTC is an interesting topic for me since I can relate this to my own teaching practice as a lecturer and an English teacher in a private English course in my hometown in Indonesia. Students who enroll in English courses are expected to be highly motivated to learn English, but, apparently, teachers of English courses still have to deal with students who do not seem interested in learning and sometimes eschew interactions with their teachers or peers. Unlike their public school fellow teachers, English teachers at language learning courses are especially required to improve their students' English competency both in spoken and written forms. To do so, they need to design classroom activities that aim to enhance students' willingness to communicate, the crucial element in language learning process.

The research was conducted within
Indonesian EFL context. Considering the limited time allocated for data collection, I decided to invite three colleagues from LBPP LIA Cirebon city and two teachers of IEDUC Bandung city (one of them cancelled her participation since she could not meet the deadline) who taught in my previous IELTS class. The recruitment of participants used purposive sampling, based on their teaching experience. All LBPP LIA teachers participated in this research have almost 15 years of teaching experience in various programs and levels, while the teacher of IEDUC has almost 10 years teaching experience and holds Cambridge CELTA from International House Teacher Training Centre, Sydney.

LBPP LIA, formerly known as Indonesian-American Foundation, was established in 1959 in Jakarta. Now the institution has branches in many major cities in the islands of Java, Bali, Sumatera, Sulawesi and Kalimantan. It provides English learning programs for children, students of junior high school (12-14 years old), senior high school (15-17 years old), EAP (English for Academic Purposes) and ESP (English for Specific Purposes) classes. The other institution, IEDUC, is a growing language institution in Jakarta and Bandung. It is well known for its qualified EAP programs, such as TOEFL, IELTS or GRE preparation classes. The branches where the participants work are in two major cities in West Java Province and Bandung City is the capital of the province.

Before the study started, I sent the letter of consent by email and asked the participants to read it carefully before they signed. The form contains information of how to participate and their rights as participants. Based on their suggestions, I did not have to ask for permission from the heads of their institutions to conduct this study. After they signed the consent form, an open ended questionnaire was sent to participants' e-mails to be completed within 3 weeks. As stated in the consent form, their answers might be followed up by other questions for 
confirmation and elaboration.

Throughout this paper, all participants appear as the pseudonyms (P1,P2,P3,P4) that were created based on the order of the submissions of their completed questionnaire.

\subsection{Data Collection Instrument}

The data in this research were obtained from an open-ended or qualitative questionnaire which I distributed to all participants by email and followed by questions to confirm or ask further explanations regarding participants' answers to the questionnaire. This section explains both stages of data collection process.

\subsection{First stage of data collection}

I decided to administer an open-ended questionnaire rather than other data collection techniques due to its efficiency considering 7 hours of time difference between the United Kingdom, where I am currently staying, and Indonesia that caused difficulty to find suitable time for interviews. The three teachers in Cirebon also informed me that questionnaire would be more suitable for them since their WIFI network was often unstable which might distract online interviews. Cohen et al., (2007) note that the open-ended questionnaire is a very effective device especially when used in a smallscale study. It may collect authentic, rich, deep and honest qualitative data. It also allows respondents to use their own terms in answering the questions (Bryman, 2008).

The questionnaire was developed mainly based on the three categories of teacher interaction strategies as proposed by Lee and $\mathrm{Ng}$ (2010): teacher-fronted, facilitator-oriented and learner-oriented and theories of teachers' beliefs, learners' WTC as well as teachers' pedagogical roles. In the first part of the questionnaire, participants were asked to define their understandings about WTC and explain how important this element is in language learning. In this part, I also checked participants' familiarity with the three interaction strategies and whether or not they use the strategies in their teaching practice. The second section focused on three parts: (1) the respondents' beliefs about the interaction strategies; (2) implementation of the interaction strategies in the classroom, (2) the impacts of the strategies to students' WTC and (3) teachers' pedagogical roles.

\subsection{Second stage of data collection}

The follow-up questions were conducted using instant messenger services such as Facebook or Blackberry messengers to confirm and elaborate upon participants' answers. For example, as all participants raised the issue of corrective feedback in facilitating learners' WTC; I used the follow-up sessions to elaborate upon how they managed the feedback; or when one participant stated that teacher-fronted strategy is an ineffective approach, I asked her to elaborate more. Therefore, each participant was asked about different topics with the number of questions at this stage depending on their previous statements. Creswell (2014, p. 191) notes that interviews using email or internet are 'useful when participants cannot be directly observed'.

Possible disadvantages of the use of email or internet interviews, however, may emerge. This instrument is time consuming for both participants and researchers. In addition to that, not all participants are able to express their stories in written form, so it is possible that they do not answer the questions clearly and completely (Cohen et al., 2007; Bryman, 2008). To anticipate the possible drawbacks, I provided sufficient time for the participants to fill in the questionnaire and answer follow-up questions.

Both initial questionnaire and follow up questions were constructed in Bahasa Indonesia. It took six weeks to complete the data collection.

\subsection{Data Analysis}

The primary data analysis was con- 
ducted following Radnor's (2002) suggestion which involves topic ordering, constructing categories, reading for content, completing the coded sheet, generating coded transcript and analysis to interpret the data. To conduct the analysis, I used Microsoft Excel spreadsheet to store the data. I did not use any computerized qualitative data processing programs as I found that Excel spreadsheet was easier for me to group participants' answers in this smallscale research. The procedure of analysing the data helped me to process and make sense of participants' answers. The following parts illustrate the details of analytical steps conducted in this process.

For the first stage of analysis, topic ordering, I prepared three Excel sheets that were named using the three interaction strategies proposed by Lee and $\mathrm{Ng}$ (2010) namely 'teacher-fronted strategy', 'facilitator-oriented strategy' and 'learner-oriented strategy'. After I received the completed questionnaire from the four participants, I started to do the second step which was constructing categories. I read over their answers and highlighted interesting and important parts of the data (Hesse-Biber \& Leavy, 2006), then I developed categories on my note based on my findings. The sample of categories is as follows:

A. Teacher-fronted strategies (TFS)
Categories:
- Levels of students
- Implementation
- Advantages
- Disadvantages
- Students' responses

After listing the categories, I reread the highlighted answers and generated initial codes.I inputted the marked questions and answers into the columns of the Excel spreadsheet and grouped them based on the topic, category. Then I generated initial codes. The next step was storing similar initial codes into one sheet for further analysis and interpretation. The analysis I developed in the previous stage would later serve as the basis of my writing.
The follow up questions were sent to participants to obtain further explanation. Less formal use of Bahasa Indonesia was chosen in the follow-up stage as this was more contexts appropriate and effective to elicit responses. The participants' answers were inserted into suitable analysis sheets. Some excerpts were chosen to be displayed in the findings section to represent other similar statements. Issues such as corrective feedback and teaching techniques were discussed in follow-up sessions. The data analysis was conducted in Bahasa Indonesia. For the purpose of this paper, the excerpts chosen to be displayed in the findings section were translated into English.

\section{Findings and Discussion}

This section presents and discusses the findings as the result of analysis and interpretation process. The excerpts shown in this part represent the answers of participants to the questionnaire which is divided into three groups based on teachers' interaction strategies proposed by Lee and $\mathrm{Ng}$ (2009).

\subsection{Findings}

The four participants had similar opinions about willingness to communicate. They noticed WTC as the trigger for students to actively participate in any classroom discourses, either with the teacher or their peers. They were also familiar with the three interaction strategies proposed by Lee and $\mathrm{Ng}$ (2009) and used the strategies in their teaching activities.

\subsubsection{Teacher-fronted strategy}

Based on their teaching experience, three participants regarded teacher-fronted strategy as an effective approach to promote students' WTC. They used this strategy for several purposes: to draw students' attention in the beginning of the class, to introduce a new topic or to remind students of the previously taught subject. 
"This strategy is useful as a "warming up' activity to start the class", (P1).

"I apply this strategy to check students' understanding or, as a reminder of previously taught topic" (P4).

On the other hand, one participant (P2) wrote that the IRF sequence was ineffective as it could not invite all students to participate in the discourses. According to P2's experiences, this strategy potentially generated students' anxiety if it was applied for more than 5 minutes. Although P2 expressed a negative perception towards a teacher-fronted approach, she still applied this strategy in her teaching activities for similar purposes as those of her colleagues. This finding is in line with the result of Li's (2013) study: a teacher may have a firm belief about something, but in the classroom might adopt contradictory approaches.

Conflicting viewpoints regarding IRF can also be seen in the literature. Some argue that this approach may aid the learning process; on the other hand, others argue that this type of strategy may constrain learning (Miao \& Heining-Boynton, 2011). Some possible negative effects of overreliance on the IRF framework may occur because of limited opportunities available for learners to exercise initiative (van Lier, 2000b cited in Waring, 2008), and to choose their own topic of interest and negotiate meaning (Nunan, 1987; Thornbury, 1996 cited in Cullen, 2002). Additionally, Cao (2011) reported that whole class interaction, which commonly occurs in IRF sequences, was considered as anxiety provoking since students may be afraid of making mistakes in front of their peers.

Conversely, this rigid exchange pattern is seen as 'a powerful pedagogic device for transmitting and constructing knowledge' (Cullen, 2002) that allows teachers to guard their large number of students in order to reach the goal of learning (Mercer 1992,1995; Wells, 1999; Lee, 2007 cited in Maroni, 2011). These supporting theories of the benefits of using the IRF triplet, however, cannot justify the use of this strategy due to the small number of students in the language learning centre classes.

All participants were aware of the authoritative nature of the teacher-fronted strategy, therefore to enhance the application of this approach, they used games, realia and audio visual media, such as pictures, short clips or songs as one of their attempts to promote students' active involvement, including reticent ones. Indeed, Budden (2011) states that audio-visual media also provide a memorable learning experience for learners.

\section{"I taught the topic of Occupations and brought pictures showing peo- ple with different kinds of occupa- tions. Students were enthusiast to guess occupations of those peo- ple in the pictures. When I asked them to mention responsibilities or duties of some occupations, they answered my questions. Later they were able to tell to the class, for instance, about what job they want to have in the future. This kind of activity makes students willing to participate" (P3).}

Although all respondents claimed that the use of classroom games was effective to stimulate students' progress, they needed to carefully design the games since the losers-winners positions created by the games might cause ill-effects for students (Hui et al., 2015). Furthermore, some students might not consider games as a useful learning activity and they would withdraw from the interactions.

From their answers, it was apparent that the respondents seriously considered building their students' self esteem. They mentioned that appraising students and carefully giving corrective feedback in the F stage were fruitful to develop students' confidence in using English. Feedback, they suggested, should be provided in an appropriate manner that would not harm students' self-confidence. This idea is supported by 
Allwright and Bailey's (1991) statement that any feedback should be delivered to provide affective support and to avoid demoralising the learners. Anxiety may reduce students' self-confidence and negatively affect one's WTC (MacIntyre et al., 1998).

Furthermore, based on their experiences, the respondents exemplified their techniques of giving feedback. All of them viewed interrupting students' talk as a potential cause of increasing students' anxiety. To avoid damaging their students' confidence, all respondents would let their students finish talking before giving correction. They used different methods to correct their students.

\section{"After finishing a session using $I R F$, I usually discuss the errors made by my students. I write the errors on the board, and together with my students, I correct them without pointing out the students who made the mistakes. Giving feedback this way, in my opinion, would not make my students (who make the errors) embarrassed, and the class may learn from the errors by correcting them together" (P2) \\ "I write (the errors) on the white- board right after the student fin- ishes the talk and show them the correct form. Sometimes I remind my students of the corrections, for example by asking 'What is the correct form of...?' or 'How do you spell the word ....' in the next IRF session" (P3)}

They agreed that it was not only students who flawlessly communicated who deserved praise and encouragement, but also those who made mistakes in order to empower them. The participants perceived praise as a means to foster students' readiness to participate in the next classroom activities. P3 also gave a paper star to any students for every correct answer. That was, she wrote, proven to successfully motivate her students to be more engaged in the exchanges.
Turning now to the possible domination of the most confident students, the participants consider it might eliminate less active students' willingness to participate. P2 admitted that it was not an easy task to manage the exchange when the fluent or active students dominated, one of her reasons for considering teacher-fronted tasks to be ineffective.

"Of course I cannot stop the active
students from answering my ques-
tions that will make the students
quit participating. At the same
time, I also need to ensure those
less active students that they have
chances to participate and I will
listen to their talk, no matter what"
$(P 2)$

To anticipate this negative situation, besides asking 'free questions' - questions to be answered by the whole class - calling on some students, especially those less inclined to volunteer, would be effective to balance opportunities within the group to answer questions. In addition to that, they also provided sufficient waiting time to encourage the reticent students to answer the given questions.

"To make sure all students participate in this question and answer session, I observe those who keep silent and ask whether or not they understand my questions. If they do not understand my questions, then I will simplify or paraphrase my questions. If their silence is due to their shyness, I usually ask other students to answer my questions first, it will give them time to prepare themselves, and when their turn comes, they will be ready to answer" (P4).

P1 emphasized good class management skills in order to effectively use the teacher-fronted strategy. P2 suggested this approach would be more suitable within higher level classes for adults since the students already had sufficient linguistic competence and self-confidence so they would 
participate more actively.

The respondents noted the ultimate pedagogical roles they performed during the application of teacher-fronted strategy were as a class manager, controller and prompter. The main goal of the implementation of this strategy and its associated pedagogical roles was to prepare their students for the next step of learning in a current session.

In summary, all participants were confident about the effectiveness of the IRF sequence to develop an active classroom interaction as long as the triplet was supported by attractive class activities and limited by time to eliminate its rigid nature. These findings are contrary to previous studies that claim teacher talk time should be minimized and students talk time should be increased as it would lead to development of students' communicative skills. However, if teachers' efforts in creating interesting exchanges can be positively accepted by their students (the students gain learning benefits), and if the students enthusiastically participate in the exchanges (which the respondents in this study regarded as a sign of willingness to communicate), it can be assumed that teacher-fronted activities, to some extent, may promote students' WTC and facilitate learning.

\subsubsection{Facilitator-oriented strategy}

Unanimously, all participants deemed the facilitator-oriented strategy as the most effective approach to develop communication in the classroom. The loose F-move in this type of IRF sequence, as P1 wrote, allowed the topic to be further elaborated while at the same time keeping it on the track. This is in keeping with Cullen (2002) who argues that if the F-move in the IRF triplet carries discoursal rather than evaluative functions; this strategy would be more student-directed. P4 echoed the advantages she gained from using facilitator-strategy approach:

"This is an effective strategy to build a manageable class discus- sion. I can control the flow of discussion to avoid domination of active students and to make sure all students have a chance to speak" (P4).

It is noticeable that both $\mathrm{P} 1$ and $\mathrm{P} 4$ maintain their control over the conversation which represents the nature of the IRF sequence. How they control a conversation that is supposed to be natural should be observed directly.

In explaining the implementation of facilitator-oriented strategy, P1 noted this strategy was applicable in all levels as long as the students were familiar with the topic and teachers were well-prepared to keep the conversation flowing. A similar opinion was proposed by P3 who also emphasized the importance of teachers' preparation.

"I should be able to identify what topic that is suitable and interesting for my students, and prepare well. I browse Internet so that the conversation would be more meaningful, not only as a means of practicing the language but also sharing the knowledge. I often have a wonderful talk with them as if it is not inside the four-wall classroom" (P1)

P2 admitted having a smooth conversation with her students without making them feel anxious was not an easy task. Her experiences made her realize the most important factor in attempting to build a conversation is to have a good rapport with the students. "They will definitely talk to me when they feel close to me" (P2). In his study, Zarrinabadi (2014) found his participants would be less anxious and more willing to communicate with teachers who were sympathetic and showed interest in their students.

Apparently, the respondents implemented the facilitator-oriented strategy through two different approaches: first, a direct conversation which usually occurred without preparation, talking about a wide 
range of topics from daily life to popular issues. The conversation itself could also be initiated by students.

"Popular or recent issue, or topics
related to their life are useful to at-
tract students to participate in the
conversation. In higher levels, stu-
dents are usually willing to share
stories or opinions and others re-
spond to their peers'stories" (P4).

Second, a prepared conversation that requires teachers to give their students sufficient preparation time and assistance. This was usually applied as a part of speaking practice. $\mathrm{P} 1$ added he also needed to ensure his students' comprehension and familiarity with the vocabulary before applying the second approach. This is in keeping with Oxford (1997) who identifies the role of teacher as a facilitator or guide and the provider of assistance, which means they provide any kinds of support that help their students to develop their language and cultural skills.

\section{"I teach Intermediate classes and the course book has a chapter ti- tled 'Who actually built the pyra- mid?'. Here students are expected to be able to differentiate myth, leg- end, hoax and hypothesis. I always apply the same techniques when I come to this topic. Before we carry out a discussion, I put my students into groups to prepare; next, each group has to give an example of myth, legend, hoax or hypothesis, other groups comment on these examples. I challenge every mem- ber of each group to have a turn to speak, either to tell the example, to express disapproval, to pose or answer questions. It works. Every- body speaks" (P1 : example of the second type of implementation).}

From the example he provided, it can be seen that P2 applied a combination of student-centred approach (by putting his students in group to complete the first phase of their task) and in the second phase, he used facilitator-oriented strategy to guide the conversation. This means that in one session, the teacher may apply more than one strategy to support another strategy he/ she uses and switch their roles accordingly.

Although the F-move in this IRF triplet is intended to create a natural conversation, the respondents still performed the role as a controller, besides the main role in this strategy which was as a facilitator of the exchanges. Given that allocating ample opportunities for students to demonstrate their language skills was urgent in reaching the main goal of language course, all four respondents believed that classroom activities should be designed to accommodate students' needs to talk, and their pedagogical roles are to provide scaffolding for their students.

\subsubsection{Learner-oriented strategy}

The learner-oriented strategy, which is manifested in group work (including pair work) and presentation, has been widely used in EFL classes due to the shift of 'teaching discrete aspects of language, such as grammar and vocabulary, to developing students' communicative competence' (Fushino, 2010, p.700). The respondents understood the main aim of this strategy was to allow students to develop the many aspects of communicative competence, which is similar to one of their own aims in teaching English. Bachman (1990) posits that ample opportunities students have in working within groups or in pairs may not only consolidate linguistic competence, but also their organizational, pragmatic, and strategic competence (cited in Fushino, 2010).

Although all four participants had strong beliefs about the effectiveness of this strategy to promote students' WTC, they also noticed that any classroom activities under the umbrella of learner-oriented strategy required more preparation. For example, they needed to choose a suitable topic for the group or pair work which could be 
taken from their coursebooks or from other sources. Sometimes they also let their students choose their topic of interest to be discussed in a session. This is in line with Williams and Burden (1997) who argue that teachers can treat their students as 'clients, partners, individual and democratic explorers'; in other words, they do not act as 'the know-it-all' who treats the whole teaching activities merely as process of transferring their knowledge to students, but they provide chances for students to participate, for example, by choosing a topic of interest.

"Being familiar with the topic of
discussion or presentation is the
key point to make students enthu-
siastically involve in (student-cen-
tred) activities. If they do not un-
derstand or are not interested in
the topic, definitely they would
eschew the process of discussion"
(P4).
"In certain level, I ask my stu-
dents to do presentation. The main
theme is based on the present topic
from the coursebook, but they can
choose any sub theme that inter-
ests them. For example, in elemen-
tary level, the title of the chapter
is 'My school', I ask my students
to choose their favourite place at
school and describe it" (P2).

The respondents also had to consider how they grouped or paired their students. P3 let her students choose their own team members as it might allow them to work comfortably. She considered a solid cooperation between all members of a group was an important element in group or pair work.

On the other hand, P1, P2, and P4 mentioned they grouped or paired their students based on students' ability. P4 pointed out that students could learn from their peers' utterances as well as correcting their peers' mistakes or gaining feedback; furthermore, they would also be stimulated to cooperate with their team members to finish the tasks.

\begin{abstract}
"I put inactive students with active ones, or those who have understood the topic better with those who understand it less. This is to avoid choosing the members in their group based on like or dislike" (P2).

"I put active students in separate groups so they might stimulate other members" (P4).
\end{abstract}

Based on their experiences in designing and applying learner-oriented activities, P1 noted that higher level students enjoyed working with their peers, either in small groups or dyads. $\mathrm{P} 2$ echoed this by relating students' positive responses and reporting that her students were actively involved in discussion with their peers. She understood this response as a sign of students' higher motivation to apply their language skills when they worked with their peers rather than as a whole class. Conversely, in their research involving 103 Brazilian EFL learners Garret and Shortall (2014) found although student-centred tasks were more fun, it did not necessarily always lead to gains in language learning., They also noticed that the teacher-fronted strategy was regarded as promoting more learning.

When using this application, the respondents admitted that they were challenged to ensure that all students attempted to use their English during their communication rather than Bahasa Indonesia or their regional languages. Without the presence of teachers, students are likely to switch the language into their mother tongue (Strong, 1983 cited in Garret and Shortall, 2014). As the respondents were also aware of it, they usually walked around the classroom to make sure their students used English, especially in higher levels. Freiermuth and Jarrel (2006) accept that L1 is useful in the language-learning classroom; however, they also point out that the reliance on L1 may hamper WTC in FL/L2 and cause little language production in the target language. Thus, teachers need to support their students to use their target language most of the time. 
On this occasion, all four respondents considered themselves as students' peers as well as motivators. They helped groups or members of groups when they seemed to face difficulties. P4 and P2's responses represented participants' answers about supervising and motivating students:

"I usually walk around to check how the discussion is carried out. When I notice a group has a problem, I sit with them and have a discussion to find possible solution" (P4).

"I use 'talking chips' to motivate students to talk in English during group discussion. The chips will be given to students who, based on my observation, actively participate in the discussion using English. A student or students who collect the most chips become the winner(s)" (P2. 'Talking chip' strategy was also implemented by P3. Both of them were from the same language centre).

Given the importance of fostering students' self confidence, all respondents highlighted careful corrective feedback during activities. They stated that direct corrections from them were unnecessary, particularly at the discussion stage since it probably would obstruct students' willingness to communicate with their peers.

\section{"I let my students carry out their discussion and correct each other within their group. My role here is as a listener. Later on, after they finish their discussion, correc- tive feedback would be given as a class" (P4).}

The participants called a student-centred activity a success if all or at least most students took active parts in the discussion to finish their task. Based on their various experiences, they elicited several possible factors that might become obstacles in this strategy including domination of active students in group discussion, uninteresting or unfamiliar topics of discussion, overuse of Bahasa Indonesia or regional languages, and insufficient or unclear teacher's explanation. To eliminate drawbacks, they prepared teaching material and gave clear instructions to set an interesting and motivating student-oriented activity.

The participants indicated that a learner-oriented classroom motivated students to communicate with their peers without feeling anxious about being closely supervised by their teachers. Students welcomed the chance to work together with their peers within small groups or dyads, for example discussion or debate, or do individual tasks as preparing and delivering presentations.

From the students' point of views that were captured by Garret and Shortall's (2014:46) study, several points might support a well-implemented student-centred task. The students felt a 'nice' and 'extroverted' teacher would be able to apply the strategy and partners who were 'nice' and 'knows as much as you do' would be helpful. In addition to that, the whole class should be 'active', 'interested', and 'united', and the subject should be 'interesting' (Garret \& Shortall, 2014:46).

Learner-fronted strategy requires more complex pedagogical roles. In preparation phase, teachers are managers, advisers, prompters, instructors and facilitators. They introduce the topic (either from book or from students' suggestion), explain the procedures of the task and put their students in group or dyad. The next step requires teachers to perform as facilitators, advisers, mediators and monitors. The last step, when students report the results of their work, teachers apply other pedagogical roles such as assessors or correctors.

\subsection{Discussion}

This study reveals that the four non-native English speaking teachers who participated in this research believe that interaction is indeed a crucial element in the process of learning the target language and a 
learning process itself takes place within the interactions (van Lier, 1996; Ellis, 2000). They also believe that students' willingness to communicate in English significantly contributes to building interactions in the target language. They manifest these beliefs in their teaching practices by making use of the strategies and pedagogical roles to develop a communicative learning process. It supports the previous studies that argue teachers' beliefs pervade their pedagogical decisions.

In respect to the first research question, it can be concluded that all of participants have firm beliefs that successful implementation of any interaction strategies largely depend on four elements: teachers' choices of teaching techniques and their understanding on students' linguistic competence, time management and students' chances to choose the topic of discussion. However, although teacher-fronted strategy does not offer the last factor, three participants still believe in its effectiveness and apply this approach to facilitate learners' WTC, while one participant does not believe in the effectiveness of this approach but applies it anyway.

The IRF sequence, that tightly controls the exchanges between teacher and students and is dominated by the teacher, has been a common practice within Indonesian EFL classes for years, especially in public schools due to the large number of students. The implementation of this strategy in language learning courses, where the ratio of teacher and students is low, perhaps is influenced by the respondents' language learning experience and the common teaching practice, but how they 'modify' the IRF application to be more interesting and communicative, as they claimed, might be the results of their in-house teachers' training and regular professional development. Following those programs become both rights and obligation of teachers in established English language courses. Lamb's (1995) study about an in-service teacher education program described how teachers interpreted ideas during and after the program might affect their actual teaching practice (Cited in Li \& Walsh, 2014). A further study can be conducted to investigate how their in-house training and professional development shape or modify their beliefs and practices.

The participants explained that they automatically adopt certain pedagogical roles based on the interaction strategy they use. All pedagogical roles they perform aim to provide scaffolding for their students.

As the answer to the second research question, there are four important steps that become the main concerns of the participants in the implementation of any interaction strategies. First, they ensure their students' familiarity with the topic; second, they creatively use realia, audiovisual media and create interactive and interesting classroom activities; third, they build rapport with their students; and fourth, they motivate and support their students. In one teaching session, they use more than one strategy and automatically apply certain pedagogical roles.

\section{Conclusions, Recommendations and Limitations}

This study indicates that a successful communicative classroom task largely depends on good teaching. It should be noted that the participants are all experienced teachers that have taught various levels of students for a number of years. They are also facilitated with realia, audiovisual media and supported by regular professional development programs. They also benefit from having a small number of students in one class which enables them to manage the class well. Their teaching experiences undoubtedly shape their beliefs ( $\mathrm{Li} \&$ Walsh, 2011) and develop their confidence in teaching. Given the importance of understanding teachers' beliefs, novice language learning course teachers' beliefs about the interaction strategies and pedagogical roles to promote their students' WTC should also be taken into account in order to develop 
deeper understandings about teachers' beliefs and their practices. Li and Walsh (2011) found that novice and experienced teachers of public schools in China hold different beliefs, therefore they also perform different practices of teaching.

In the light of the results, teachers as a central part of the learning process are entitled to fulfill their prominent task, which is to enhance learners' communicative skills; consequently, they should understand the construct of WTC, recognize the elements that facilitate or debilitate it (Zarrinabadi, 2014), as well as formulate and apply appropriate strategies to develop it. Within
Indonesia's EFL teaching context, the concept of WTC should be introduced to student-teachers during their training and highlighted in any language teacher professional development programs.

The complexity of teachers' beliefs and their actual teaching practice needs to be investigated using both interviews and observations since a combination of the methods would elicit more reliable data (Li \& Walsh, 2014). This study points to the need for further research that offers the breadth and depth of teachers' beliefs and practices.

\section{References}

Allwright, D., \& Bailey, K. M. (1991). Focus on the language classroom: An introduction to classroom researcher for language teacher. Cambridge: Cambridge University Press.

Budden, J. (2011, April 6). Teaching English. Retrieved January 12, 2015, from British Council: http://www.teachingenglish.org.uk/language-assistant/teaching-tips/realia

Cao, Y. (2011). Investigating situational willingness to communicate within second language classrooms from an ecological perspective. System , 468-479.

Cheng, X. (2013). Research on Chinese College English Teachers' Classroom Code Switching: Beliefs and Attitude. Journal of Language Teaching and Research, 4 (6), $1277-$ 1288.

Choudhury, A. S. (2011). Classroom Roles of English language Teachers : The Traditional and The Innovative. Contemporary Online Language Education Journal , 33-40.

Clandinin, D. J., \& Connelly, F. M. (2000). Narrative Inquiry: Experience and Story in Qualitative Research (Education). San Fransisco, CA: Jossey-Bass.

Cullen, R. (2002). Supportive teacher talk : The importance of F-move. ELT Journal , 117 127.

Dörnyei, Z., \& Murphy, T. (2003). Group Dynamics in the Language Classroom. Cambridge: Cambridge University Press.

Freiermuth, M., \& Jarrell, D. (2006). Willingness to communicate: can online chat help? International Journal of Applied Linguistics , 189-212.

Fushino, K. (2010). Causal relationships between communication confidence, beliefs about group work, and willingness to communicate in foreign language group work. TESOL Quarterly, 44, 700-724.

Garrett, P., \& Shorttall, T. (2002). Learners' evaluation of teacher-fronted and student-centred classroom activities. Language Teaching Research , 25-27.

Harmer, J. (1998). How to Teach English. Essex: Longman.

Hedge, T. (2000). Teaching and Learning in the Language Classroom. Oxford: Oxford Uni- 
versity Press.

Hesse-Biber, S. N., \& Leavy, P. (2006). The Practice of Qualitative Research. Thousand Oaks, California: Sage Publications, Inc.

Hung, H. C., Young, S. S., \& Lin, C. P. (2013). No student left behind: a collaborative and competitive game-based learning environment to reduce the achievement gap of EFL students in Taiwan. Technology, Pedagogy and Education, 24, 35-49.

Ingram, J., \& Elliot, V. (2014). Turn taking and 'wait time' in classroom interaction. Journal of Pragmatics, 1-12.

Kang, S. (2005). Dynamic emergence of situational willingness to communicate in a second language. System , 277-292.

Lee, W., \& Ng, S. (2010). Reducing student reticence through teacher interaction strategy. ELT Journal, 64 (3), 302-313.

Li, L. (2013). The complexity of language teachers' beliefs and practice : one EFL teacher's theories. The Language Learning Journal, 41, 175-191.

Li, L., \& Walsh, S. (2011). 'Seeing is believing' : Looking at EFL teachers' beliefs through classroom interaction. Classroom Discourse, 2, 39-57.

Liu, M., \& Jackson, J. (2008). An Exploration of Chinese EFL Learners' Unwillingness to Communicate and Foreign Language Anxiety. The Modern Language Journal, 92 (08), 71-86.

MacIntyre, P. D. (2007). Willingness to communicate in the second language: Understanding the decision to speak as a volitional process. The Modern language Journal , 564-576.

MacIntyre, P. D., Dörnyei, Z., Clemént, R., \& Noels, K. A. (1998). Conceptualizing Willingness to Communicate in a L2: A Situational Model of L2 Confidence and Affiliation. The Modern Language Journal, 82 (4), 545-562.

Maroni, B. (2011). Pauses, gaps and wait time in classroom interaction in primary schools. Journal of Pragmatics , 2081-2093.

Miao, P., \& Heining-Boynton, A. L. (2011). Initiation/Response/Follow-Up, and Response to Intervention:Combining Two Models to Improve Teacher and Student Performance. Foreign Language Annals , 65-79.

Oxford, R. L. (1997). Cooperative Learning, Collaborative Learning and Interaction: Three Communicative Strands in the Language Classroom. The Modern Language Journal , 443-456.

Pajares, F. M. (1992). Teachers' beliefs and educational research:cleaning up a messy construct. Review of Educational Research, 307-332.

Radnor, H. (2002). Researching your professional practice. Buckingham: Open University Press.

Rido, A., Ibrahim, N., \& Nambiar, R. M. (2014). Investigating EFL Master Teacher's Classroom Interaction Strategies: A Case Study in Indonesian Secondary Vocational School . Procedia Social and Behavioral Sciences , 420-424.

Ryoo, H. K. (2009). Language Related Episode (LRE) in Learner Interactions as an Opportunity for Language Learning. English Teaching, 315-335.

Zarrinabadi, N. (2014). Communicating in a second language : Investigating the effect of teacher on learners' willingness to communicate. System, 42 (4), 288-295. 